\title{
THE POSTGRADUATE'S OPINION OF HIS UNDERGRADUATE MEDICAL EDUCATION
}

\author{
A. G. W. Whitfield, M.D., Ph.D., F.R.C.P. \\ Director, Board of Graduate Studies, University of Birmingham
}

IN order to obtain accurate information in respect of emigration among Birmingham medical graduates, all those qualifying in medicine from the University of Birmingham in the eleven years 1948-58 were recently asked to complete a proforma giving information regarding what type of medical work they are now doing and where. The emigration data have already been published (Whitfield, 1963), and also a summary of the present sphere of work and postgraduate achievements of the 976 graduates concerned (Whitfield, 1964).

The graduates were invited to submit with the proforma their opinion of the undergraduate education and training they received and their suggestions as to how the curriculum might be improved. The majority did not accept this invitation and many of those who did offered nothing but praise and gratitude. However, $268(27.5 \%)$ put forward some criticisms or ideas as to how the undergraduate course might be ameliorated and this communication summarizes their opinions.

It is not for one moment suggested that as far as undergraduate medical education is concerned 'the customer is always right', indeed many of the criticisms and suggestions put forward clearly reflected a regret that the curriculum was not specially directed to the particular branch of medicine which the graduate concerned had chosen to enter. Nevertheless, much of the criticism was intelligent, constructive and balanced and provided data that it is thought will be of value to those who are interested in and responsible for undergraduate medical education.

Most would agree that the day of purely vocational undergraduate medical training is past and that increasing attention should be paid to the cultivation of a scientific approach to medicine and to the development of an intellectual capacity to reap the harvest of postgraduate training and the wide, rapid and ever-increasing advances in medicine in a critical and intelligent manner. This concept has been most ably propounded by many of the leaders in the medical educational field (Arnott, 1959, Ellis, 196r) and is slowly gaining acceptance.

Furthermore, no-one would dispute that it is impossible to teach an undergraduate all that is known or to train him fully for any branch of medicine he may subsequently choose to enter in a period of five years, and that postgraduate training to equip him for his particular sphere of work and continued education for the remainder of his professional life, are necessary for all. Nevertheless, many British graduates still enter general practice, sometimes as principals, immediately after they have completed their preregistration appointments and those who embark upon postgraduate training for a specialty must have a secure foundation of knowledge of all branches of medicine on which to build their special aptitude and skill. The vocational aspect is therefore still important and its relevance to the life-work of all graduates compels attention.

Before considering in detail the criticisms and suggestions that were offered it is apposite to examine the sphere of work of those who advanced them. This is summarized in Table I from which it will be seen that those who have chosen to enter general practice or to specialize in psychiatry were more critical than the rest. Nearly one half of the graduates $(49.3 \%)$ are engaged in general practice or psychiatry and $63.8 \%$ of the criticisms and suggestions emanated from these groups. It is difficult therefore to escape the conclusion that the University of Birmingham did not provide during the years in question an undergraduate training and education that made entry into these branches of medical practice an easy matter.

In this context it must be pointed out that, during the years covered by this survey, there was no university department of clinical psychiatry and the only facilities for undergraduate experience of general practice were an elective two-week period of attachment to a general practitioner from 1952 onwards. From 1951 to 1957 there was a chair of experimental psychiatry 
TABLE I

\begin{tabular}{|c|c|c|c|c|c|c|c|c|}
\hline $\begin{array}{l}\text { Branch of } \\
\text { Medicine }\end{array}$ & $\begin{array}{l}\text { General } \\
\text { Practice }\end{array}$ & $\begin{array}{l}\text { Armed } \\
\text { Forces }\end{array}$ & $\begin{array}{l}\text { Anæs- } \\
\text { thetics }\end{array}$ & $\begin{array}{l}\text { Public } \\
\text { Health }\end{array}$ & $\begin{array}{l}\text { Psy- } \\
\text { chiatry }\end{array}$ & Surgery & Medicine & Patholog \\
\hline $\begin{array}{cr}\text { Percentage of } & 976 \\
\text { graduates } & \text { so } \\
\text { engaged } & . . \\
\end{array}$ & 44.9 & 6.1 & 6.0 & 5.4 & 4.4 & 4.0 & 3.0 & $2.2 \underset{\vec{F}}{\stackrel{\vec{F}}{\underline{C}}}$ \\
\hline $\begin{array}{l}\text { Percentage of } 268 \\
\text { graduates offer- } \\
\text { ing criticisms or } \\
\text { suggestions . . }\end{array}$ & 56.0 & 5.2 & 4.5 & 3.7 & 7.8 & 1.5 & 2.6 & $2.2 \frac{\bar{D}}{\frac{\bar{D}}{D}}$ \\
\hline
\end{tabular}

TABLE 2

\begin{tabular}{|c|c|}
\hline $\begin{array}{l}\text { Specialty of } \\
\text { which teaching } \\
\text { criticized }\end{array}$ & $\begin{array}{l}\text { Number of } \\
\text { criticisms or } \\
\text { suggestions }\end{array}$ \\
\hline $\begin{array}{ll}\text { Psychiatry . } & \ldots \\
\text { General Practice } & \ldots \\
\text { Dermatology } & \ldots \\
\text { Ophthalmology } & \text {. } \\
\text { Otorhinolaryngology } \\
\text { Prescribing }\end{array}$ & $\begin{array}{r}109 \\
68 \\
79 \\
49 \\
40 \\
28\end{array}$ \\
\hline
\end{tabular}

but the activities of this department were never strongly directed to undergraduate education.

The largest number of criticisms or suggestions were in respect of psychiatry (Table 2): 109 $(40.7 \%)$ of the 268 felt that this subject had been taught inadequately but only 18 of the 109 were actually engaged in the practice of psychiatry and the majority of the criticisms (62 of Io9) emanated from those engaged in general practice. On numerical grounds alone these opinions cannot be disregarded and the terms in which they were couched clearly indicate that the faults and omissions have become more obvious to the consumer than they ever were to the onlooker. The major defects that were voiced were a complete lack of teaching of psychology, a failure of clinicians to pay any real attention to psychological illness and the fact that psychiatric teaching was virtually confined to the demonstration of hopeless cases of psychotic illness, who had been inmates of mental hospitals for many years, to the exclusion of the common psychiatric illnesses such as anxiety and depression. It will not surprise readers to know that a university department of clinical psychiatry has now been established and that many of the errors of a decade ago have already been remedied.

Sixty-eight $(25.4 \%)$ of the 268 complained of a lack of experience and knowledge of general practice and of illness in the home as opposed to in the hospital: 48 of the 68 who made this criticism were engaged in general practice perhaps reduces the force of their argumen⿳亠口冋t the short-comings of the traditional practiee Sof confining undergraduate medical education o acute general hospitals has been pointed out Hy $^{2}$ Ellis (196r) and is fully recognized in the Birmirgham plan for a balanced hospital community (McKeown, 1958, I961). Black (1959) also Beported that a group of Manchester students $\supset$ at their final examination complained of inadequate experience of general practice.

Seventy-nine $(29.5 \%)$ of the 268 felt that teaching of dermatology was inadequate. these 79,65 were engaged in general practiče: $49(17.9 \%$ of 268$)$ expressed similar opinions regarding ophthalmology and 40 (14.9\% of 268 ) werre dissatisfied with the training they had received 3 n otorhinolaryngology. Of these latter groups 33 zof the 49 complainants regarding ophthalmology and 29 of the 40 who thought their undergradugate training in otorhinolaryngology was inadequate were engaged in general practice. During the eleven years of undergraduate education coo which this survey relates, Birmingham medical students were required to spend a period cof three calendar months in the study of th three specialties, devoting two days per week to each. In addition two lectures per week $7 \mathrm{~h}$ ophthalmology and one lecture per week on otorhinolaryngology were available through\&ut one academic term and a proportion of the 
medicine lectures were allotted to dermatology. Dermatology, ophthalmology and otorhinolaryngology comprise between them a large and important part of general practice but one would have thought the time allotted to these specialties and the instruction given adequate. Indeed since $195^{8}$ both have been reduced. However the opinions voiced by the graduates concerned, particularly those who have chosen to enter general practice indicates that this was not the case. Many medical educationists would feel that training in these specialties is a postgraduate rather than an undergraduate function and the Board of Graduate Studies of the University of Birmingham in co-operation with the Birmingham Regional Hospital Board are now planning to establish six post-registration 'rotating internships' which will provide this type of special experience for those planning to enter general practice. Even so, it appears desirable to focus more attention on these specialties during the undergraduate years and perhaps their greater inclusion in the final examination may be more important than the allotment of a longer period in the undergraduate schedule to them.

Twenty-eight (10.4\%) of the 268 mentioned lack of instruction in prescribing drugs: 22 of these 28 were general practitioners and this criticism, though important, probably stems from the differing requirements of hospital and general practice as pre-registration house officers are constantly prescribing for the patients for whom they are responsible. Nevertheless, more undergraduate instruction in this aspect of medicine is perhaps desirable as during the years in question and even now it is confined to a series of fifteen lectures in management and therapeutics a:d the issue of a brief list of drugs in everyday use, showing their dosage and cost.

A vast number of other criticisms and suggestions were advanced by small numbers of graduates. Many of these were frivolous and impractical while others though only put forward by a minority were thought to be most relevant and important.

Regarding the clinical years, 5 of the 268 graduates pointed out the poor experience they had obtained during medical clerking or surgical dressing on highly specialized firms: 8 referred to the large part of their surgical dressership that was spent holding on to a retractor in the theatre, and 9 considered that their clinical teachers put too much emphasis on rare diseases and not enough on the common maladies. Six would have welcomed more opportunity for student residence in hospital and 9 considered that more use should be made of non-teaching hospitals. Similar opinions were expressed by the group of final year students whose opinions Black (1959) reported.

The arrangement of the curriculum necessitates that a small group of undergraduates are required to sit Part $I$ of the final examination during their period of obstetric residence and 4 graduates pointed out the difficulties of doing justice to both.

Teaching methods did not escape criticism: 8 asked for the exclusion of lecturers who had no capacity to teach and little apparent interest in their teaching responsibilities. Three asked for more tutorials and fewer lectures and I suggested that more use should be made of clinicopathological conferences.

The content of the curriculum was chiefly criticized on the grounds of omission of important branches of medicine. Thus 8 graduates considered that there should have been some special teaching of geriatrics, 6 would have wished for more attention to have been paid to preventive medicine and public health and 9 pointed out that no instruction in marriage guidance was given. An absence of any instruction in medical ethics was commented on by 3 graduates and 8 would have welcomed a greater experience of clinical pathology and biochemistry. More important perhaps were the remarks of 3 graduates who said that they were not taught how to use a medical library and of 5 who regretted that they had had no research training. Other omissions that were commented upon were tropical medicine, physical medicine, medical electronics, the social services, the National Health Service and the British Medical Association. It will be appreciated that many of these criticisms referred to the curriculum as it was IO-I 5 years ago and some of the subjects then omitted such as geriatrics are now included in the undergraduate training programme, on an optional basis.

The curriculum was also criticized on the grounds of both bias and balance. Five graduates considered that they received too much instruction. in forensic medicine, a subject which has now been excluded from Part I of the final examination, and instruction in which has been incorporated with other subjects: I4 felt that their instruction in social medicine was insufficiently related to their subsequent professional life and 2 of them felt they would have benefited from a greater knowledge of industrial medicine and occupational health. The pre-clinical subjects came in for little adverse comment but 8 of the correspondents felt that the teaching of anatomy and physiology should have had a stronger bias to clinical practice and that clinicians should play a larger part in their teaching.

Among the other comments and criticisms were lack of careers guidance and the absence of an 
adequate tutor system. The latter has been very efficiently developed over the last decade.

These criticisms and suggestions of Birmingham medical graduates concerning their undergraduate education and training are not published under the delusion that they provide a formula for a perfect undergraduate curriculum. Indeed it is hoped they will not retard the mutation from vocational training to undergraduate education as it should be. In the provision of all commodities and services it is important to know what the consumer thinks and there is no reason to believe that undergraduate medical education is an exce्gtion to this rule.

I am very greatly indebted to the Nuffield Provinçial Hospitals Trust for a grant which covered the experises of this investigation and my warm thanks are also to all the Birmingham medical graduates who responfed so generously to my request for their views about क्the undergraduate education and training they received.

\section{REFERENCES}

ArnotT, W. M. (1959): The Climate of Medical Education, Lancet, i, r.

BLACK, D. A. K. (1959): Consumer Interests, Lancet, i, 673.

ELLIS, J. R. (1961): Professional Practice and Medical Education, f. med. Educ., 36, I 19.

McKkown, T. (1958): The Concept of a Balanced Hospital Community, Lancet, $i$, 701 .

(1961): Limitations of Medical Care Attributable to Medical Education, Lancet ii, $\mathbf{r}$.

Whitrield, A. G. W. (1963): Medical Emigration Among Birmingham Graduates, Lancet, ii, 874.

- (1964): Current Work of Birmingham Medical Graduates 1948-58, Lancet, i, 374. 